\title{
Nat Turner after 9/11: Kyle Baker's Nat Turner
}

Abstract: Scholars have thoroughly questioned what Nat Turner meant to others in the past; in this article, I question what he means today. Reversing William Andrews's injunction to read "Prophet Nat's" 1831 insurrection through the US's encounter with religio-political terrorism on 9/11, I instead examine the effect September 11th has had on the rebel slave's contemporary afterlife. Ultimately this article asks what cultural work Nat Turner now performs, what his most recent depictions tell us about the racial formations of the present. Drawing on comics theory, I parse the visual rhetoric of Kyle Baker's popular and increasingly studied comic Nat Turner, in which Baker tropes Nat Turner as Christ just as Nat Turner himself did in his Confessions. Baker produces an inviolably iconic black hero, one who is visually antithetical to racist images of "the terrorist" circulating in post-9/11 discourses on national belonging. By doing so, Baker effectively safeguards not only Nat Turner but US "blackness" from Islamophobia during the age of the Global War on Terror. Finally, by reading Baker's comic alongside other recent, unexamined depictions of the rebel slave, this article critically intervenes by updating the archive on Nat Turner and complicating the political possibilities that inhere in other sites of memory.

Nat Turner's spirit still roams the US, to paraphrase Sterling Brown's poem "Remembering Nat Turner” (1939). ${ }^{1}$ It does so through depictions of the iconic slave rebel such as Sharon Ewell Foster's recent Christian novel series The Resurrection of Nat Turner (2011-2012). Foster's novels consciously revise much of Nat Turner's afterlife, the legacy of cultural productions and discourses that have continually made and remade his image in popular culture. Although he has been portrayed as a patriot-martyr during the Civil War, a rallying figure for black radicalism in the 1930s, and variously as a religious fanatic or Black Power revolutionary in the 1960s, little is known about the man's life before 1831. That year, this slave preacher led an insurrection in Southampton, VA, claiming that God had sent him apocalyptic visions urging him to wage war against slavery. He and a handful of conspirators began traveling by night between houses in

1 Sterling A. Brown, "Remembering Nat Turner," The Collected Poems of Sterling A. Brown, ed. Michael S. Harper, (Evanston: TriQuarterly Books/Northwestern UP, 1996). 
their neighborhood, freeing slaves and killing whites in their sleep. By the time that Nat Turner's growing band was stopped by a militia, the insurgents had killed approximately sixty whites. Nat Turner himself would escape arrest for two more months before being captured, dubbed a religious fanatic, tried, and executed. The uprising, meanwhile, had made national headlines and precipitated a wave of white insurrection anxiety and repressive slave codes. ${ }^{2}$ Foster supplements the gaps in Nat Turner's personal history and rewrites his accepted story. For example, she reimagines an Afrocentric Nat Turner, a humble, religious son of Ethiopian Christians who remembers and remains deeply in love with his African heritage. But in order to safeguard Foster's celebration of the self-identified prophet in all of his black positivity, The Resurrection of Nat Turner must also countenance the anxieties of a post-9/11 US. After Foster's Nat Turner and his fellow slaves spill the first blood of their insurrection, the slave-preacher-turnedfreedom-fighter panics. Badly shaken by killing his owners, Nat Turner "closed himself to what he had seen and done” so that he might continue his war. ${ }^{3}$ At this moment of disorienting violence, the text scrambles to reassure readers of the insurgents' righteousness by conspicuously dubbing them "Knights Templar executing a plan of battle.”4

Here Foster deploys Christianity—specifically referencing the “Knights Templar,” historical Christian crusaders against Muslim peoples-as shorthand for Nat Turner's moral

2 Many summaries of the facts of the Southampton insurrection are available, often including important primary materials. See in particular Henry Irving Tragle, The Southampton Slave Revolt of 1831: A Compilation of Source Material (Amherst: University of Massachusetts Press, 1971); Eric Foner, Nat Turner (Englewood Cliffs: Prentice-Hall, 1971); and Kenneth S. Greenberg, ed. The Confessions of Nat Turner and Related Documents (Boston: Bedford/St. Martin's, 1996). See also Stephen B. Oates, The Fires of Jubilee: Nat Turner's Fierce Rebellion (New York: Harper \& Row, 1975) for the standard narrative account of the revolt and Scot French, The Rebellious Slave: Nat Turner in American Memory (Boston: Houghton Mifflin, 2004) for a comprehensive history of Nat Turner in cultural memory through the 1970s.

3 Sharon Ewell Foster, The Resurrection of Nat Turner, Part Two: The Testimony (New York: Howard Books, 2012), 252.

4 Ibid. 
rightness. Having portrayed Islam as a sinister presence earlier in the story, the text now uses a Christian/Islam comparison to maintain readers' support for the bloody insurrection. Much of the series actually focuses on Nat Turner's Ethiopian Christian mother, Nikahywot, whose enslavement in Ethiopia is precipitated by a Muslim raid on her village: she and her family “fled . . . from the ones who said they were followers of Islam, the new religion, from the schemers who twisted the words of the prophet Muhammed for profit.” ${ }^{5}$ Although the identities of her kidnappers remain unknown, the character's enslavement only occurs through her encounter with Islam. ${ }^{6}$ The comparison of Nat Turner's band of rebels to Christian crusaders belies an impulse to absolutely distinguish his “Knights Templar” from the "schemers” of Islam by using the same Christian crusader rhetoric that, since 11 September 2001, has been incorporated into a clash-of-civilizations discourse that justifies US imperialism in the Middle East as a response to an "Islamist" threat to "the West."7

By deploying the racialized opposition of Christian/Muslim in support of this icon of black militancy, Foster complicates the way we should read Nat Turner after 9/11. Her novels should prompt critics to reconsider the cultural work that the sign "Nat Turner" now performs.

As a controversial, contested black icon, Nat Turner also represents a site in which the very

5 Sharon Ewell Foster, The Resurrection of Nat Turner, Part One: The Witnesses (New York: Howard Books, 2011), 207.

6 Foster's texts hedge their depiction of Muslims. For example, Nat Turner's grandmother Afework insists that "All Muslims cannot be evil. [The Muslim kidnappers] are the greedy ones, the connivers who use religion to get what they want” (ibid., 209). Yet the novels never actually depict any Muslim characters: Islam only appears obliquely, either as a metonymy for the threat of enslavement in Africa or as the implied other to Nat Turner's "Knights Templar."

7 President George W. Bush provides an early example in a speech from 16 September 2001. Speaking of the 9/11 hijackers at the White House, Bush declares that "we need to be alert to the fact that these evil-doers still exist. We haven't seen this kind of barbarism in a long period of time. ... This is a new kind of - a new kind of evil. And we understand. And the American people are beginning to understand. This crusade, this war on terrorism is going to take a while." George W. Bush, "Remarks by the President Upon Arrival," White House South Lawn, Washington, DC. 16 Sept. 2001, Presidential Remarks: http://georgewbushwhitehouse.archives.gov/news/releases/2001/09/20010916-2.html. 
meaning of US blackness becomes contested and defined. Parsing his most recent cultural afterlife helps reveal that since 9/11 and the global War on Terror, race has been remade. By conflating blackness with the Islamophobic specter of the "terrorist” in recent years, the national (and local) security state's white imagination has birthed a truly post-9/11 racial formation. But anxiety over the stability of racial signs manifests in other recent Nat Turner texts besides Foster's novels. Eisner, Harvey, and Glyph award winner Kyle Baker offers the most salient and increasingly studied depiction of “Prophet Nat” in decades. Along with Mat Johnson's Incognegro (2008), Baker's comic Nat Turner (2005-2007) has become a canonical example of African American literature in comics. And like Foster's novel series, Baker's comic reactively asserts the slave rebel's iconic image as inviolate: the comic visually re-deploys Nat Turner's own Christological self-troping in The Confessions of Nat Turner of 1831. It doubles-down, so to speak, on his original rhetorical strategy in order to inoculate his legacy against comparisons to our own contemporary, racially coded image of religious zealotry: the "terrorist.”"

The global War on Terror has rendered unstable the distinction between icon and terrorist, prophet and fanatic. Tentatively, scholars have begun drawing connections between Nat Turner and the nation's encounter with religio-political terrorism since September $11^{\text {th }}$. Bertrand WyattBrown places the slave rebel in conversation with 9/11 when he praises Charles Burnett's 2002 documentary about the competing interpretations of Nat Turner, Nat Turner: A Troublesome Property. Wyatt-Brown writes, "In light of current dread of terrorist assaults, [Burnett's film] boldly takes on special meaning." " Likewise, in a challenging 2008 essay titled "The Confessions

8 I do not argue that Kyle Baker's Nat Turner belongs in the by now well-established canon of 9/11 literature, a collection of texts that directly respond to the event, including David Foster Wallace's "The Suffering Channel” (2004), Art Spiegelman's In the Shadow of No Towers (2004), Jonathan Safran Foer's Extremely Loud and Incredibly Close (2005), Don DeLillo's Falling Man (2007), and Thomas Pynchon's Bleeding Edge (2013). Rather than engage 9/11 per se, Nat Turner exhibits, through its representational strategies, anxiety about the instability of US blackness under the post-9/11 War on Terror's regime of global white supremacy.

9 Charles Burnett, Nat Turner: A Troublesome Property, (2002, California Newsreel), DVD. 
of Nat Turner: Memoir of a Martyr or Testament of a Terrorist?,” William Andrews asks us to read the historical Confessions "in light of the late-twentieth-century rise of religious terrorism" in order to see what such a cultural formation might tell us about Nat Turner, and to see what he might tell us back about our own time. ${ }^{10}$ Indeed, Andrews goes so far as to posit the rebellious slave as a "proto-religious terrorist."11 Andrews acknowledges that a comparison between this iconic black figure and the events of 9/11 appears incendiary, but he insists that "given the similarities between the rhetoric of dehumanization and demonization that constituted official reaction to Turner and his followers in most media in the antebellum United States and to the AlQaeda terrorists in much contemporary U.S. media, we have reason to ask what we can learn from a fresh look at Turner, and in particular his Confessions, through a post-9/11 perspective.”12 My intention in this essay, like Andrews's, is to read Nat Turner via 9/11. Unlike Andrews, however, I want to take a particular term within the complex of 9/11-era discourses—namely, the figure of the "terrorist" - and position it in relation to the black icon's textual afterlife rather than his historical person. Doing so both updates the ongoing story of Nat Turner as an active cultural presence and helps us to make sense of a salient feature of our contemporary racial landscape: the conflation of Islamophobia and anti-black racism.

The image of the "terrorist" that emerges after the September $11^{\text {th }}$ hijackings is a composite of competing discourses. It is at once an imagined anti-American insurgent, Muslim extremist, and raced other. The figure is a fantasy, of course, what we now call an Islamophobic one. "Islamophobia,” however, proves an inapt description since the concept often fissures

10 William L. Andrews, “The Confessions of Nat Turner: Memoir of a Martyr or Testament of a Terrorist?,” in Theorizing Scriptures: New Critical Orientations to a Cultural Phenomenon, ed. Vincent L. Wimbush (New Brunswick: Rutgers UP, 2008), 83.

11 Ibid., 84.

12 Ibid. 
between religion and race, subsuming a diversity of racial identities regardless of religio-cultural identification. Rather, Islamophobia has become a nativist ideological formation of white supremacy that antagonizes not only Muslims but also people of color designated as "foreign," especially brown-skinned people and people of Middle Eastern, Central and South Asian, and North African descent. Slurred as "looking like terrorists," they have become highly salient targets in the post-9/11 era's global War on Terror. Yet in the white imagination of the US, the racial signification of the "terrorist” becomes further unstable as our Islamophobia draws inspiration and occasion from, or often transforms into, anti-black racism. ${ }^{13}$

Perhaps no one more memorably expresses the articulation of one form of oppression to the other than James Baldwin. When discussing black nationalism, the Nation of Islam, and Elijah Muhammad in The Fire Next Time, Baldwin allegorizes the relationship between blackness and Islam: "God, going north, and rising on the wings of power, had become white, and Allah, out of power, and on the dark side of Heaven, had become—-for all practical purposes, anyway—black."14 Here Baldwin points to the historical antecedent for the racial formation I am positing. However, for a uniquely post-9/11 rendering of the way Islam becomes racially coded as black, and vice versa, one needs to look no further than the controversial New Yorker cover of

13 See Janani Balasubramanian, “Zimmermans and Drones: Antiblackness and Global Domination,” Black Girl Dangerous (blog), 8 Aug. 2013, http://www.blackgirldangerous.org/2013/08/201388zimmermans-and-dronesantiblackness-and-global-domination/, as well Cornel West, interview by Amy Goodman, Democracy Now!, 22 July 2013, in which West declares that "President Obama is a global George Zimmerman" for his use of drone warfare, drawing a comparison between US racist imperialism and the vigilante murder of Trayvon Martin. For example, the War on Terror and US anti-blackness converge in the 2009 plot of the so-called Newburgh Four. Four black Muslims from a Newburgh, NY mosque were convicted of plotting terrorist acts, yet their plan was actually concocted by a paid FBI informant who aggressively courted their involvement. The four men variously display undiagnosed mental illnesses, have been incarcerated, or have suffered dire poverty. According to Paul Harris in The Guardian, “It is not a portrait of radical Islamists. It is a sad picture of life in an urban ghetto.” In the case of these four men, the state rhetorically transubstantiated the consequences of its racist socio-economic policies into a terrorist threat that could sanction the state's national security apparatus. Paul Harris, "Newburgh Four: poor, black, and jailed under FBI 'entrapment' tactics,” The Guardian, 12 Dec. 2011, http://www.theguardian.com/world/2011/dec/12/newburgh-four-fbi-entrapment-terror.

14 James Baldwin, The Fire Next Time (New York: Dell, 1962), 66. 
21 July 2008. “The Politics of Fear” by Barry Blitt depicts then-Presidential candidate Barack Obama dressed in a turban and shalwar kameez standing in the Oval Office; Michelle Obama is rendered like Angela Davis and wearing the garb of a stereotyped Black Power militant. She and her husband perform the so-called "terrorist fist-bump" that conservative pundits fixated on during the 2008 election. In the background, a portrait of Osama bin Laden hangs over the fireplace, in which a US flag burns. ${ }^{15}$ Whether read as satire or played straight, The New Yorker cartoon aptly represents the growing union of and undecidability between two racial identities in the contemporary white imagination. Perhaps it was because the cartoon lays bare the marriage of blackness with the "terrorist" by way of the Obamas' own marriage that the image initially drew such condemnation.

I want to use Islamophobia in Foster's novels as a way to begin reading Kyle Baker's Nat Turner. To be sure, Islamophobia never manifests in Baker the way it does in Foster, whether on the surface or at a depth. Rather, the fraught relationship between Islamophobia and antiblackness that I have briefly outlined constitutes the cultural ground for any post-9/11 representation of the iconic slave rebel given that he lies at the intersection of racial and religious militancies. ${ }^{16}$ Beginning with Foster's novels as I have done reveals the ways in which memorializing iconography can operate in this register of cross-racialization. Thus, they provide critics with a productive reading of the representational strategies of other Nat Turner texts as well as of memory studies writ large.

Although others have celebrated Nat Turner as an icon in the past, Baker's depiction is

15 Barry Blitt, “The Politics of Fear,” New Yorker, 21 July 2008, cover.

16 I consider it an open question whether the same will hold true for Nat Turner in the advent of the Black Lives Matter movement in 2013 following the acquittal of George Zimmerman in the case of Trayvon Martin's murder. Perhaps Black Lives Matter will ultimately shift that cultural context for Nat Turner from the convergence of anti-blackness and Islamophobia to something else, to something even liberatory and movement-oriented. 
perhaps unique in so thoroughly inhabiting the same Christological terms that he used in 1831. The comic's visual-verbal logic re-deploys Nat Turner's own rhetorical strategy in order to shortcircuit associations of the rebel-preacher—and his blackness—with the anathematized specter of the "terrorist.” Like Foster's absolutist assertion of difference between the slave "crusaders" and Muslims, what I term Christological iconography functions in Baker's comic both to preempt Nat Turner's critics by aligning him with a privileged cultural category and to define his blackness against their criticism. By Christological iconography, I simply mean those representational strategies that visually render Nat Turner as Christ-like. In the historical Confessions of Nat Turner, the confessor himself frames his actions according to soteriological and apocalyptic Christian tropes, an interpretive schema that would make his "work of death"17 intelligible and justifiable to his nineteenth century contemporaries. Although less radical today, the re-deployed Christological troping still performs a similar cultural work for contemporary audiences. What remains the same is that both depictions of Nat Turner attempt to marginalize readings of the man as a religious "enthusiast," as his contemporaries called him, by identifying him with Christ himself. But the determinant difference lies in the 2005 comic's post-9/11 context. The image of Nat Turner-as-Christ now erases that of Turner-as-“terrorist,” the Islamophobic, raced category that also haunts Sharon Ewell Foster's more recent depiction. Baker leaves, then, no room for imputations of religio-political "terror," our contemporary version of nineteenth century “enthusiasm.”

Because scholarship on Nat Turner has so focused on his competing depictions in the 1960s and '70s, a time when the white Southern novelist William Styron's portrayal of the rebel as a sexually repressed fanatic provoked a vociferous response from black cultural nationalists, no attention has been paid to the contemporary significance of Nat Turner himself, to his still

17 Greenberg, Confessions, 48. 
unfolding afterlife. By theorizing the collective meaning of his most recent iterations, then, I not only offer a new interpretation of the black icon; I also expand his cultural archive, our record of his representations and remembrances in popular culture. ${ }^{18}$

Serialized from 2005 to 2007, Kyle Baker's comic Nat Turner constitutes not only the first forthright depiction of the Nat Turner story since 9/11 (it is a retelling rather than, say, a documentary like Charles Burnett's 2002 film), but also his most significant cultural appearance since Styron's much contested 1967 novel, The Confessions of Nat Turner and John Henrik Clarke's riposte, Ten Black Writers Respond (1968). With Nat Turner, Baker retells the story of the iconic slave insurrectionist through a mostly wordless, black-white-and-gray comic. When Baker does utilize written text, typically for the purposes of narration, he draws primarily from the historical record on slavery: he excerpts most of the text from the sections of The Confessions of Nat Turner of 1831 that are written in Nat Turner's voice, although one of Baker's scenes utilizes the voice of the Confessions's white amanuensis, while another scene utilizes a passage from Theodore Canot's Adventures of an African Slaver. However, historical text is not incorporated within the illustrated narrative itself through, for example, word or thought bubbles, but rather it remains in the comic's gutters. ${ }^{19}$ Text and image in the comic are typically set against one another in such a way as to create a double narrative that begins in Africa before Nat Turner's birth and ends approximately at his execution in Southampton. At times Canot's text or that of The Confessions only serves as exposition for Baker's images. At others, his images supplement the historical texts with a more intimate look at the relationships and sufferings of black people

18 Furthermore, since I aim to move critical engagement with Nat Turner beyond the '60s and '70s, I intentionally spend little time on his intertexts from those decades in the present essay.

19 One scene stands out as an exception as it depicts a young Nat Turner with fellow slave children eating from a trough in a visual allusion to the famous “mush” scene in Frederick Douglass's 1845 autobiography, as Baker himself points out in the footnotes. See Kyle Baker, Nat Turner (New York: Abrams, 2008), 70, 204. 
than what history has usually allowed. Still at other moments, the tension between image and text, between slave experience and dominant history, becomes so stark as to create an ironic contrast.

Baker claims that his own self-education served as impetus for the project. In the preface to the Abrams edition, the black writer-artist explains that "I often choose to write books on subjects I wish to know more about. I wanted to know how a person nobody wanted to talk about could be arguably one of the most important men in American history." ${ }^{20}$ Baker avows ${ }^{21}$ that his is a revisionist depiction, one inspired by Malcolm X's telling of “the slave preacher Nat Turner, who put the fear of God into the white slavemaster" and whose "example is said to have inspired John Brown.”22 Baker aims for his comic, which was eventually published by Abrams with an eye toward educating students, to break what he sees as the decades-long silence about the man. ${ }^{23}$

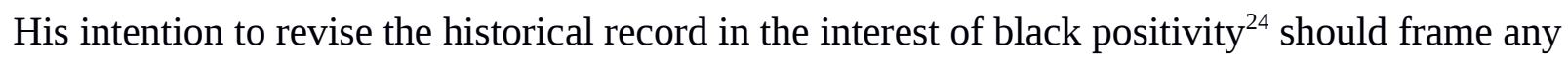
approach to his comic. Thus I contend that Baker leaves us with a version of Nat Turner that is, like Foster's, celebratory, but a celebration accomplished by way of the comic's formal irony. ${ }^{25}$

20 Ibid., 6.

21 Ibid.

22 Malcolm X, The Autobiography of Malcolm X, (New York: Ballantine Books, 1964), 179.

23 Jamin Brophy-Warren, "Rebel Yell: A book tells the story of Nat Turner's uprising -in cartoon form,” Wall Street Journal, 2 Aug. 2008, W2, http://online.wsj.com/news/articles/SB121764057720406573.

24 Baker, Nat Turner, 7. Urging black self-reliance, Baker admonishes readers to "Think about it" and trumpets the fact that this, one of his first independently published works, is about a self-educated, "self-freed slave."

25 The body of criticism on Baker's comic has been most concerned with the implications of retelling the Nat Turner story through the medium of comics; in particular, scholars have focused on the precise nature of the relationship between text and image in the comic given Baker's juxtaposition of his own pictorial narrative with excerpts from historical documents from the archive on US chattel slavery. In the main, critics hold that text and image in Nat Turner function ironically, as I have said: for Andrew Kunka, the image/text tension is an example of the comic's signifying on Nat Turner's intertexts, including the original Confessions; for Consuela Francis, the ironic contrast revises the generic conventions of the slave narrative; and for Jonathan Gray, image/text functions to critique the historical archives on both Nat Turner and slavery. Although I will draw on their work for key critical interventions, I do not read Baker as being so ambivalent or openly critical about Nat Turner's 
Celebrating the black insurgent would not be possible, however, if the comic itself encouraged readers to draw connections between Nat Turner's struggle and contemporary instances of religio-political violence. But by telling Nat Turner using a diversity of artistic styles, Baker is able to deploy particular aesthetics at key narrative moments in order to shape reader interpretation. Of course, Baker's aesthetic across his oeuvre is eclectic. Comics such as The Bakers (2006) or Plastic Man (2004-2006) are illustrated in a ludic cartoon mode, while comics such as Special Forces (2007-2009) or “Hawkman” in Wednesday Comics (2009) employ a highly stylized aesthetic with pulp references. In Nat Turner, Baker uses this stylistic promiscuity to the fullest effect. Multiple visual styles track across the comic, such as Baker's use of photo-realistic houses, weapons, and a printing press for the purpose of shifting scenes, particularly in "Freedom." No better example illustrates this type of polystylism than Will's last stand at the climax of the insurrection. Will's highly stylized physique and the hyper-violence of his final battle with the white militiamen spectacularize the revolt. Whereas Will is initially depicted using deep charcoal shading and cross-hatching suggestive of realistic human form, emotional depth, and Will's concealed hatred for whites, in the final confrontation of the revolt he has exploded into full view with sharp, clean lines. His limbs now bulge out of all proportion to the rest of his body as he decapitates whites with a single swing of his axe and clutches severed arms while gore and bits of clothing spray around him. ${ }^{26}$ The result is the "compelling graphics," "action and suspense," and "superhuman abilities” that Baker sought to highlight in the Nat Turner story. ${ }^{27}$ By deploying a style reminiscent of superhero comics, Baker brings forth

legacy as do some of these scholars. See also Celeste-Marie Bernier, Characters of Blood: Black Heroism in the Transatlantic Imagination (Charlottesville: University of Virginia Press, 2012) and Michael A. Chaney, "Slave Memory Without Words in Kyle Baker’s Nat Turner," Callaloo 36, No. 2 (2013): 279-297, http://muse.jhu.edu/ for other recent work on Baker's comic.

26 Baker, Nat Turner, 107-08, 174-75.

27 Ibid., 6. 
what he sees as the superheroic in militant slave resistance. As I will further discuss below, the sequence that portrays Nat Turner's execution also deploys a purposeful style, this time to signify reverence, holiness, and a degree of realistic physicality as components of a Christological iconography.

The ironic relationship between Baker's art and the text of The Confessions of Nat Turner bears significantly on the problem of Nat Turner's post-9/11 afterlife. Most of our knowledge of the man and his rising has come from this historical document, now a canonical work of African American literature. Most importantly, the text describes Nat Turner's alleged motivation: inspired by visions from "The Spirit that spoke to the prophets in former days" to "take [Christ's yoke] on and fight against the Serpent," "Prophet Nat" gathered a band of fellow slaves to attack local whites and strike for freedom as part of "the great day of judgment." 28 According to Eric Sundquist, the literary significance of The Confessions lies in its representativeness as "pathway from the world of colonial jeremiad to that of secular revolution," as one among many "acts of resistance [that] have meant far more to readers of the day and generations to follow." ${ }^{29}$ The text purports to be the insurrectionist's confession upon his imprisonment, but like other primary sources on slavery, including many slave narratives, The Confessions is conflicted and highly mediated. It was dictated to a white amanuensis, the lawyer (though not Nat Turner's) Thomas R. Gray, who copyrighted the text on 10 November 1831, the day before the rebel's execution. For most of its history, scholarship on Nat Turner has been ambivalent regarding the interpretation of such a poly-vocal text: who is confessing? Nat Turner or Thomas Gray? Precisely how much of Nat Turner do readers experience? Which are his words, his ideas, and which belong to his white interlocutor and the oppressive legal apparatus that he represents? Literary scholars such as

28 Greenberg, Confessions, 46-47.

29 Eric J. Sundquist, To Wake the Nations: Race in the Making of American Literature (Cambridge: Harvard UP, 1993), 21, 31. 
Sundquist and William Andrews have split the interpretive difference, arguing that "this is a text divided against itself, in which there is a fundamental competition between two opposing wills for the power that comes from the act of appropriation, the power to endow and legitimate a self with mythic significance,”30 a series of “statement and counterstatement of revolutionary principles." ${ }^{31}$ Within the semiotic tension of The Confessions, just as in his textual afterlife, “The meaning of Nat Turner is perpetually postponed." 32

The most persistent criticism of the preacher-rebel was leveled by Gray within the very pages of the Confessions. The white lawyer attempts to portray Nat Turner as both a demonic fiend and a religious fanatic by dubbing his religiosity “enthusiasm.”33 “'Enthusiasm,' as William Andrews explains, "was a class-conscious word used pejoratively by high-church conservatives to denigrate evangelical fervor as little more than an anarchical excess of the imagination.”34 Despite Nat Turner's longstanding association with religious extremism, Baker's text actually precludes imputations of fanaticism: the comic skillfully pits Christian iconographic imagery against historical text as a principle strategy for short-circuiting readers' association of Nat Turner, as preacher-cum-insurgent, with racialized discourses on religious terrorism that arose in the aftermath of September $11^{\text {th }}$. Scholars of memory studies, neo-slave narratives, and other modes of historical fiction have long noted that setting a narrative within the historical past serves to critique a text's contemporary moment. Yet the comic's contemporary moment was one in which religious violence against the state-terrorism—-had recently provoked a reactive

30 William L. Andrews, To Tell a Free Story: The First Century of Afro-American Autobiography, 1760-1865 (Urbana and Chicago: University of Illinois Press, 1986), 72.

31 Sundquist, Wake the Nations, 37.

32 Andrews, Free Story, 77.

33 Greenberg, Confessions, 44.

34 Andrews, Free Story, 73. 
nationalism against many people of color and preceded US occupations of multiple

predominantly Muslim countries. In order to tell, in such a moment, the story of this black rebel who was inspired by God to kill whites in their homes and topple the central national institution of his time, Baker would have to disrupt presentist readings of his comic. In Sharon Ewell Foster's The Resurrection of Nat Turner, that disruption comes through establishing Muslims as a sinister, enslaving presence and figuring Nat Turner as an anti-Islamic crusader.

In contrast, Baker utilizes diverse visual modes in order to create counter-meaning against the white archive, ending with a Christological iconographic sequence of Nat Turner's "passion” as a visual allusion to Christ's crucifixion. The conclusion visually encourages readers to interpret Nat Turner as like Christ rather than damn him as an "enthusiast" as Gray did or as a “terrorist” as US readers would. The image/text dichotomy that is so foundational to comics, deployed in tandem with the visual aesthetics of Nat Turner, wards off presentist readings of the comic and the specter of fanatical religious violence against the state that was still so prominent in the years following 9/11. What results is a celebratory counter-image of the rebel slave as icon, as Christ. As Consuela Francis so aptly puts the matter, "It is only when coupled with Baker's narrative images that Turner's prophecy, and the violence that ensues, takes on a righteous weight” rather than the madness that his detractors have long assigned him. ${ }^{35}$

In attempting to define the nature of the medium, comics theorists have pointed to the importance of interplay between text and image. ${ }^{36}$ Scott McCloud's now canonical definition of comics as "juxtaposed pictorial and other images in deliberate sequence" minimizes the

35 Consuela Francis, “Drawing the Unspeakable: Kyle Baker's Slave Narrative,” in Comics and the U.S. South, ed. Brannon Costello and Qiana J. Whitted (Jackson: UP of Mississippi, 2012), 119.

36 See Andrew J. Kunka, "Intertextuality and the Historical Graphic Narrative: Kyle Baker's Nat Turner and the Styron Controversy,” College Literature 38, No. 3 (2011): 187-88, http://muse.jhu.edu/ for a succinct summary of comics' two competing theoretical camps. He also asserts that Kyle Baker's Nat Turner "presents particular challenges” for both of the primary definitions of the comics form (ibid.,188). 
significance of the written word for the art form, but subsequent theorists have dissented. ${ }^{37}$ In particular, Robert C. Harvey emphasizes instead "the economy of expression achieved by visualverbal interdependence,” asserting that the comics form depends primarily on a mutual exchange of meaning between picture and word ${ }^{38}$ Hillary Chute corroborates, writing that "Comics contain 'double vision' in their structural hybridity, their double (but non-synthesized) narratives of words and images. In one frame of comics, the images and the words may mean differently, and thus the work sends out double-coded narratives or semantics,” producing a "contradictory flow" held "in tension.” ${ }^{39}$ These formulations are especially useful in studying Baker's comic of Nat Turner. Since the text of the historical Confessions is always set against Baker's art instead of incorporated within it, the two materials supplement one another but just as frequently critique or revise each other in the "contradictory flow” that Chute describes. According to Francis, "Baker's use of the comics form, his bringing together of narrative images (not merely illustrative ones) with Turner's words, gives a 'complete' picture of Turner's life, while also calling into question the very notion that we can ever know Turner's 'complete' story. The 'ironic' relationship between the words and pictures allows Turner's graphic slave narrative to convey meaning differently than it does alone.”40 I contend that comics' disconnect between image and text that Harvey and Chute theorize, that Francis expressly cites in Baker as irony, frames the iconographic style that Baker eventually uses to depict Nat Turner. That is, by dwelling at length on an image/text irony that ultimately critiques the historical archive, the comic prepares readers to privilege Baker's

37 Scott McCloud, Understanding Comics (New York: HarperPerennial, 1994), 9.

38 Robert C. Harvey, "How Comics Came to Be: Through the Juncture of Word and Image from Magazine Gag Cartoons to Newspaper Strips, Tools for Critical Appreciation plus Rare Seldom Witnessed Historical Facts,” in A Comics Studies Reader, ed. Jeet Heer and Kent Worcester (Jackson: UP of Mississippi, 2009), 26.

39 Hillary Chute, “Comics as Literature? Reading Graphic Narrative,” PMLA 123, No. 2 (2008): 459-60, http://www.mlajournals.org/.

40 Francis, “Drawing the Unspeakable," 120. 
Christological illustrations of Nat Turner that conclude the text.

Baker first introduces the ironic interplay of text and image in the initial book of Nat Turner, “Home.” The comic opens with a facsimile reproduction of the title page of The Confessions, clearly situating the illustrated narrative that follows in relation to the historical archive on slavery. The facsimile serves first, perhaps, as an authenticating device à la slave narratives, but ultimately as an object of critique and signification. It is Baker's comic with its look at the intimate details of slavery rather than the historical document that provides an account of the "WHOLE INSURRECTION," as Gray advertises of The Confessions. ${ }^{41}$ At the same time, Baker's deployment of the facsimile may well challenge Gray's own attempt at authentication as well as the antebellum racial logic that required whites to vouchsafe for the autobiographical accounts of black authors. Following this early interpolation of the archive into the comic, a wordless story unfolds in which an African woman is kidnapped by African slavers, is enchained and brutally marched to the coast, and finally sold to slave traders. She is, as the reader eventually learns, Nat Turner's mother, and as she is processed for transportation across the Atlantic Ocean a single-panel page depicts her being clutched by ghoulish, disembodied white hands as she stares fearfully at a glinting razor held in front of her. Below the panel is the first significant text of the comic: "FROM THE MEMOIR OF CAPTAIN THEODORE CANOT: Twenty Years of An African Slaver: The head of every male and female is neatly shaved; and, if the cargo belongs to several owners, each man's brand is impressed on the body of his respective negro. ... They are entirely stripped, so that women as well as men go out of Africa as they came into it—naked."42 From this point the pictorial narrative details the horrors of the Middle Passage—signified, in particular, by the threatening sharks in the ocean-which include

41 Baker, Nat Turner, 10.

42 Ibid., 36. 
starvation, deaths on board, beatings, and finally the auction block. Here the comic shifts, ending by juxtaposing Baker's images against text "FROM THE CONFESSIONS OF NAT TURNER" in which Nat Turner describes his divine knowledge of "things that had happened before my birth."43

Thus "Home" is structured by beginning, middle, and end references to the historical archive. In between, though, Baker's pictorial narrative "fills the gaps” in the textual record on the Atlantic slave trade and US chattel slavery. ${ }^{44}$ Here again Baker utilizes multiple visual styles. When Nat Turner's mother is stripped for branding, Baker portrays her as a cartoonish silhouette, all black, with cartoonish white hands grasping from off-panel; both are set against a blurred photo-realistic image of a slave coffle with slave ships in the distance. The cartoonishness imparts a sense of immediacy, intimacy, and life-in-motion in contrast to the historical background even as the historical authenticates the foregrounded scene. ${ }^{45}$ Baker's depiction of Nat Turner's mother's face is still more significant for considering image versus text. Throughout this section and regardless of Baker's choice of artistic style in a given panel, her face is drawn with stark clarity. Her eyes in particular organize panels or draw readers' attention. The panel that includes Canot's text exemplifies this tactic. White bodies and hands dominate the panel yet remain obscured or vague because they are heavily shaded and merely sketched. Yet her face, her fists, eyes, and the gleaming razor stand out due to Baker's sharp line work. ${ }^{46}$ The focus on her face in turn focuses readers on the personal. In this way, the comic indicts lacunae in official history by juxtaposing Canot's distant and dehumanizing description of slave trading against

43 Ibid., 57.

44 Francis, “Drawing the Unspeakable,” 131.

45 Baker, Nat Turner, 33.

46 Ibid., 36. 
Baker's depiction of the intimate lived horrors of slavery. Nat Turner's original subtitle, "the master's masterpiece updated,” encapsulates this irony even as it suggests the privileged status of the comic's images. ${ }^{47}$

This interaction between image/text irony and visual style stands out in the affecting twopage spread in "Freedom," in which a Kara Walker-esque ${ }^{48}$ silhouette depicts Will being gunned down by four presumably white men. ${ }^{49}$ The highly stylized imagery of Will's last stand has here been reduced to cartoonish all black shadows, but the focus on Will's body surrounded by his own bloodspray and the other dismembered bodies still proves chilling. In fact, the page implicates readers within the scene: as McCloud notes, higher degrees of visual abstraction, simplicity, or “cartoonishness” universalize and thus invite "viewer-identification,” whereas higher degrees of visual complexity and realism objectify the subjects being depicted. ${ }^{50}$ Reducing Will to his cartoonish silhouette, then, forces readers to empathize with the slave. But this full page is further juxtaposed against “A List of Persons Murdered in the Insurrection,” which is actually a list of the whites killed during the uprising as taken directly from The Confessions. Read together, the pages reveal that dominant history remembers neither the violence of slavery nor the names of most of the black people it destroyed. As with Baker's tracking of Nat Turner's mother's face in "Home," there would be no irony, no emotive effect, between image and text in

47 Quoted in Jonathan W. Gray, “'Commence the Great Work': The Historical Archive and Unspeakable Violence in Kyle Baker's Nat Turner,” in Afterimages of Slavery: Essays on Appearances in Recent American Films, Literature, Television, and Other Media, ed. Marlene D. Allen and Seretha D. Williams (Jefferson: McFarland, 2012), 183.

48 For a discussion of Baker's silhouette of Will in relation to Walker's work, see Marc Singer, "Week 8: Kyle Baker, Nat Turner.” I Am NOT the Beastmaster (blog), 18 Mar. 2010, http://notthebeastmaster.typepad.com/weblog/2010/03/week-8-kyle-baker-nat-turner.html.

49 Baker, Nat Turner, 178-79; see Figures 1 and 2.

50 Scott McCloud, Understanding Comics (New York: HarperPerennial, 1994), 42. For an overview of the spectrum of "realism” to "abstraction," see 36-53. 
these two pages without the strategic use of form to create reader responses. The visual project works only if there is an assumption of insufficiency or deficiency in the (historical) text that Baker's images can supplement or revise by way of their strategic aesthetic. And it is precisely this dynamic that enables Baker to create a Nat Turner who is not a terrorist, but, instead, even more than a martyr: a Nat Turner who is visually Christ crucified.

Indeed, the title of the fourth and final book foreshadows a Christological victory-indeath. "Home” depicts a violent diaspora. "Education” depicts slavery's active disruption of cultural and social forms of knowledge. And "Freedom" depicts the failure, in the grossest sense, of a slave uprising. Finally, “Triumph,” depicts the imprisonment and execution of the comic's eponymous protagonist. ${ }^{51}$ Besides reinforcing the importance of irony throughout the comic, this paradoxical titling implies a logic of worldly-failure-turned-spiritual-victory that has a long history in Christianity. Just as Christ's death on the cross is refigured as a victory over sin and death, Nat Turner ultimately triumphs through the textual dissemination of his words despite his execution. In the Abrams edition, the title of the fourth book is even juxtaposed against a splash page depicting Nat Turner's limp body hanging by the neck from a tree. ${ }^{52}$ This image initiates the comic's properly iconographic depiction of Nat Turner. The scene is notable for its scale: the massive tree, ray of sunlight, and long hanging rope all dwarf the human figures at the bottom of the page. Indeed, the distance needed to take in the entire scene swallows the identities of the subjects; this could as easily be any lynching as Nat Turner's execution. Yet readers understand that this is the end of the slave rebellion. They understand too that the scene is reminiscent of Christ's crucifixion. The light shining down from the sky, the taut lynching rope, and the trunk of the tree all converge at the hanged corpse. The effect is to connect Nat Turner not to the obscene, 51 For a discussion of the four book titles as signifying on the trajectory of the classic slave narratives, see Bernier, Characters of Blood, 139.

52 Baker, Nat Turner, 186. 
raucous crowd but to the sublime scale of the page's top portion. The effect is to render Nat Turner not in terms of the human but in terms of the divine.

Like “Home” especially, “Triumph” is all but wordless. In this book, however, Baker drastically manipulates the historical text, namely, The Confessions, in a novel way: whereas excerpts of the 1831 Confessions have previously been introduced as "FROM THE CONFESSIONS OF NAT TURNER," in "Triumph," the same text is introduced as "FROM THE RECORD OF THOMAS R. GRAY."53 That is, Baker separates the competing authorial voices of The Confessions. On one hand, this distillation poses Nat Turner's authorial voice earlier in the comic as unmediated by the white Southern legal apparatus; on the other hand, this poses Gray as the culminating and representative example of the white archive, therefore enabling Baker to make a final critique of the historical text by contrasting it with his Christological images of Nat Turner. Set in the gutter below a single panel that depicts Nat Turner speaking to Thomas Gray in a jail cell, we find a key passage from The Confessions, now described as Gray's legal notes, that attempts to portray "Prophet Nat" as a madman:

The calm, deliberate composure with which he spoke of his late deeds and intentions, the expression of his fiend-like face when excited by enthusiasm, still bearing the stains of the blood of helpless innocence about him; clothed with rags and covered with chains; yet daring to raise his manacled hands to heaven, with a spirit soaring above the attributes of man; I looked on him and my blood curdled in my veins. ${ }^{54}$

The reader's gaze is positioned above the two men, at a distance. Baker's blurred line work and cross-hatching emphasize the separation between viewer and viewed. The facing page

53 Ibid., 188.

54 Ibid. 
is pivotal to the interpretive arc of the comic. Like the previous page, this one consists of a single panel with text below in the gutter. The reader's perspective is from over Gray's shoulder, thus obscuring his face, drawing attention to a close-up of Nat Turner's own face. Below the figures, arranged respective to the speaker, is the significant question-answer exchange between the two men as taken from The Confessions: “Question: 'Do you not find yourself mistaken now?' Answer: 'Was not Christ crucified?'”55 Nat Turner's gentle, almost beatific face foils the Gothic image of the "fiend-like” insurgent presented by Gray in the historical text. Though Baker's shading and cross-hatching again might create obscurity from the reader's gaze, this technique also softens Nat Turner's features, visually transforming him from an apocalyptic prophet into a compassionate Christ-like figure. Further, the textual voice of Nat Turner in this passage is here deployed in tandem with the visual-verbal irony of the comic for the sake of a final, damning critique of the historical record now captured in the phrase "FROM THE RECORD OF THOMAS R. GRAY.” This sequence finally disrupts the relationship between image and text operating thus far in the comic, a rupture adroitly represented in the subsequent panel when Gray snaps his pen nib in shock at Nat Turner's self-identification with Christ. ${ }^{56}$

When Nat Turner casts himself as Christ in the historical Confessions, his "audacity here at the climax of his narrative turns Christ into a type," according to William Andrews, "a historical prefiguration of himself, the ultimate bearer of the responsibility for the eschaton in which whites will be judged and blacks redeemed." ${ }^{57}$ Further, this "language of prophecy was the medium in which Turner worked," writes Sundquist in To Wake the Nations, because it was one of the "principal semiotic systems in which the African slave found himself placed," and through

55 Ibid., 189; see Figures 3 and 4.

56 Ibid., 190.

57 Andrews, Free Story, 75. 
creative reading it could be made to serve his own radical purpose. ${ }^{58}$ Thus, in spite of Gray's presence in the text, The Confessions of Nat Turner becomes another move in what Sundquist calls the preacher's “guerrilla assault," even his “terror,” by rendering him as the "black Christ of the South.”59 This jail cell self-identification with Christ—an act which Gray himself cannot contain as The Confessions's white editor-has been called by Andrews "the most audacious tropological reading of Scripture in nineteenth-century black autobiography.”60 It perhaps best exemplifies "the tropological turn" that Andrews identifies in eighteenth and nineteenth century African American letters, in which the spirituals and some black autobiographies "invited a reading of biblical precedent in terms specific to the secular aspirations of American slaves” or “projected their lives as secular figurations of scriptural mythoi.”61

This moment of Christological troping is climactic for the comic. Nat Turner actually prepares readers for this scene by meditating on the act of tropological reading. One of the key moments in "Education” immediately follows the escape of Nat Turner's father from the family's master. As the textual voice of Nat Turner relates how he learned to read, his pictorial, adolescent counterpart is depicted stealing a Bible and surreptitiously reading it behind a cabin. ${ }^{62}$ Four panels appear concurrently with the textual description of Nat Turner's acquisition of literacy. In each panel, a foregrounded Nat Turner reads the Bible while the scenes that he reads are rendered in the background, specifically, scenes of the Israelite captivity in Egypt and their

58 Sundquist, Wake the Nations, 81.

59 Ibid., 72, 69, 81. It is worth noting that accounts of Nat Turner's execution and his afterlife in black folklore also depict him Christologically, notably including reports that his corpse bore the stigmata (Ibid., 82-83).

60 Andrews, Free Story, 72.

61 Ibid., 61-62.

62 Baker, Nat Turner, 85. 
Exodus led by Moses. ${ }^{63}$ The tropological value of the Exodus story is readily apparent to readers of African American literature. Israel's captivity frequently serves as a metaphor or type for black enslavement in the US, as can be recognized in spirituals such as “Go Down, Moses.” The young slave's early encounter with the Biblical story here becomes a means by which to understand his own experience of enslavement and inspires the adult preacher's fiery sermons after the sale of his family later in the comic. ${ }^{64}$

Yet despite the significance of Biblical types to the comic, Nat Turner actually sidelines religion qua religion, unlike Foster's avowedly Christian novels. Baker's readers never glimpse Nat Turner's visions, for example. Instead Baker attempts to negotiate the tension between fully depicting this story that contains religious fervor at its core, on the one hand, and marginalizing “enthusiastic" readings of "Prophet Nat" on the other. Thus at what should be Nat Turner's moment of conversion, Baker seems to critique religious sentiment. Following Nat Turner's discovery of the Exodus story, the textual narrative draws from The Confessions as follows: "Growing up among [the Negroes in the neighborhood] with this confidence in my superior judgment, and when this, in their opinions, was perfected by Divine inspiration, from the circumstances already alluded to in my infancy, and which belief was ever afterwards zealously inculcated by the austerity of my life and manners. ...”65 However, this passage reads against Baker's illustrations below it. Here, the young Nat Turner attends a prayer meeting at which worshipers shut their eyes and throw up their hands in praise during a sermon-but the boy is rendered apart, his hands down and eyes wide, possibly in shock or disbelief. The preacher, it turns out, contrasts sharply with his audience: he dresses ostentatiously, less like the poor slaves

63 Ibid., 86-87.

64 Ibid., 104-05.

65 Ibid., 91. 
he sermonizes to than the Zip Coon character who later saves his master from Nat Turner's band $^{66}$; further, the preacher's finery is rendered black, standing out against the plain, white, presumably homespun clothes of the worshipers. He cuts a ridiculous figure against Nat Turner's professed “austerity,” while the reference to Nat Turner's “superior judgment” reads the worshipers critically. They have been taken in by a charlatan, the juxtaposition implies.

Whether such scenes indict religion generally, they do mitigate the role of religious feeling even as the text utilizes religious tropes as a representational strategy against post-9/11 readings of “enthusiasm.” Before the reader's very eyes, Kyle Baker's Nat Turner learns to read his own life tropologically, engaging in a reading strategy that had by the antebellum period come to define African American literature. But the reader learns to read tropologically along with the comic's protagonist too. This sequence prepares the audience for the Christological imagery that ends the comic. By the final page of the text, Nat Turner's appropriation of Christ's role as suffering redeemer (and judge) appears not as religious fanaticism so much as a valid strategy for making sense of life lived under oppression.

Significantly, Nat Turner's Christ-troping in his cell ends the textual narrative of Nat Turner. Once Gray breaks his pen nib, the comic continues wordlessly until its end in a kind of triumph over the white archive. The jailhouse shifts to a two-panel page depicting a family picnicking and children playing. Baker renders their faces in rounded, almost cartoonish fashion. However, the introduction of Nat Turner on the following pages disrupts the sense of ease that their facial features create. ${ }^{67}$ As throughout the rest of the comic, Baker draws the adult Nat Turner with a long, lean face and sharp, angular features that bespeak gravity. The higher degree of realism here objectifies Nat Turner for readers, making him more “real” as per McCloud. In

66 Ibid., 132.

67 Ibid., 191-93. 
objectifying him rather than inviting reader identification, Baker also distances readers from the rebel slave in a way that creates a sense of inscrutable holiness. In this respect, his introduction into this sequence proves especially marked and, indeed, reverential. A two-panel page further juxtaposes his serene, upturned face against the white mob jeering and throwing food, followed by the sun shining through storm clouds. ${ }^{68}$

The subsequent full page panel acts as a key iconographic moment: portraying Nat Turner in close-up, eyes closed and at peace as the noose is tightened around his neck, creates a beatific effect. ${ }^{69}$ Baker all but draws a halo around his head. From here, the panels proceed showing first the expectant, enthusiastic faces of the crowd, then those same faces wide-eyed, perhaps stunned or disappointed. ${ }^{70}$ Their eyes direct the reader to the adjacent page and its single panel. Nat Turner's limp, motionless body hangs from a tree by a rope. The tropological education that readers have received alongside Nat Turner prepares them for Baker's visual cues. The frontal view of Nat Turner's body, the sharp outline of his form that emphasizes its limpness, and his head turned delicately to the side all visually allude to commonplace depictions of Christ's crucifixion. Further, the treeline frames his body in what first appears to be a white cloud; the result is an aura-effect that imbues the scene with a sense of awe, even holiness. ${ }^{71}$ Baker further emphasizes the miraculous stillness of Nat Turner's death, glossing the page with a note explaining that "Nat Turner did not die kicking and suffering as hanged men usually do. He simply rose into the air, breathing his last, peacefully without twitching a muscle."72 That Nat

68 Ibid., 193.

69 Ibid., 194.

70 Ibid., 195-96.

71 Ibid., 197; see Figure 5.

72 Ibid., 204. 
Turner "rose into the air" as if of his own accord recalls Christ's ascension into heaven, and the remaining pages of the text suggest that he wields in death a profound spiritual power as a symbol to other slaves. The execution scene eventually shifts to show a white man laying a book on a table, which is quickly absconded with by a household slave who reads the book in secret. ${ }^{73}$ The sequence of the slave stealing literacy, itself a common trope in slave narratives, ends Nat Turner, though not before Baker reveals that the cover of the stolen book is actually the title page to The Confessions of Nat Turner, which appeared in facsimile on his comic's first page.$^{74}$ From Nat Turner's “crucifixion,” readers have now progressed to his discursive "resurrection.”

Like the Middle Passage in "Home” or the slaughter of black insurrectionists in "Freedom,” the Christ-like execution of Nat Turner in "Triumph” simultaneously "fills the gaps" of official history, as per Francis, even as it signifies upon the historical record. Baker locates historical critique and supplement within the graphic narrative in a canny manipulation of the most basic formal properties of the medium of comics; but Baker also poses that critique and supplement by using aesthetic form to make a visual argument. In the final book, "Triumph,” Baker assembles pictorial cues that reference other depictions of Christ or that otherwise connect Nat Turner to the divine in order to create what I have called an iconographic style. When contrasted with “THE RECORD OF THOMAS R. GRAY,” this style transforms into an argument for tropologically reading Nat Turner as Christ. He becomes the messiah so central to the nineteenth century's white Protestant culture and not, as Gray would have it, a bloodthirsty demon "excited by enthusiasm." According to the visual-verbal logic of the comic, the reader ultimately witnesses to a Nat Turner who is Christ himself. ${ }^{75}$

73 Ibid., 198-200.

74 Ibid., 200.

75 My interpretation of Baker's Nat Turner as an unambiguously Christ-like figure runs counter to readings by Gray and Kunka. Gray, “'Commence the Great Work,’” 186 asserts that Baker pointedly rejects "a hagiography 
As writers represent Nat Turner by marshaling Christian crusaders and resurrecting Christ, we would do well to question what role iconography as a rhetorical strategy plays in attempting to fix and define blackness in the US against other targets of white supremacy when their racial signifiers begin to blur. The discomfiting echo between acts of religio-political violence in the nineteenth and twenty-first centuries certainly bears consideration, as other scholars have already suggested. But the more urgent significance of Nat Turner's contemporary afterlife rests in what it can tell us about the continual remaking of race, particularly after 9/11. I want to conclude, then, with a final example from Nat Turner's post-9/11 afterlife that, like the Foster and Baker texts, iconographically celebrates blackness at a time of acute threat. But unlike the texts above, this cultural moment attempts to dislocate anti-blackness from Islamophobia without reference to Christian symbolism. In February 2013, former police officer Christopher Dorner began a campaign of what he called "unconventional and asymmetrical warfare” against the LAPD. ${ }^{76}$ Dorner had been fired from the Department in 2009 for alleging that his partner brutalized a man suffering from schizophrenia while on patrol. According to Dorner, who was black, his subsequent firing was only another instance of the LAPD's long history of entrenched racism and corruption, including the Rampart scandal and the Rodney King beating. In retaliation in 2013, Dorner killed two police officers, another officer's daughter, and that woman's fiancé, prompting a massive and highly publicized manhunt that resulted in Dorner's death. ${ }^{77}$ Dorner himself

of Nat Turner.” Kunka, “Intertextuality,” 186 makes an intriguing argument that Baker's Nat Turner is an intertextual composite of competing representations of the iconic figure, including of him as "a devil to be driven out by a white savior,” namely, by Benjamin Phipps. However, Kunka misidentifies Phipps with an unnamed, vaguely “Christ-like” white character whom Will actually decapitates.

76 “Document: Manhunt Manifesto,” Los Angeles Times 7 Feb. 2013, http://documents.latimes.com/christopherdorner-manifesto/.

77 The LAPD's response, however, often resembled vigilante justice as officers fired upon people they mistook for Dorner and eventually burned down his hideout while he was still inside. During a shootout at the cabin which 
proved difficult to defend due to his use of violence, particularly against civilians and people of color. ${ }^{78}$ But many people did defend him—as Nat Turner come again.

Maybe it was in order to make sense of Dorner's difficult violence that many came to read him as a black folk hero "rebelling” against the "slavery" of the LAPD. On Facebook, groups appeared such as "We Stand With Chris Dorner," "We Are All Chris Dorner,” and “Chris Dorner and the Revolution,” with these three alone having a combined 33,881 followers in April 2013. ${ }^{79}$ The latter group, in particular, describes Dorner's actions as "his revolt.” Others went so far as to draw comparisons between Dorner and Nat Turner himself. One Twitter user writes, "Chris dorner considered armed and dangerous and extremely black . . . this is the nat turner of our time” (sic). Another writes that "Chris Dorner went Nat Turner ...,” and another that "Chris Dorner is officially the Nat Turner re-incarnate of 2013. Way to kick off [Black History Month] by righting the wrongs of the system.” Still another writes that "Chris dorner our modern age Nat turner. Masta gonna be scare now you hear?” (sic).$^{80}$ Of course, Chris Dorner was never an actual

Dorner had occupied, police used incendiary tear gas that set the building ablaze. The LAPD asserts that Dorner committed suicide by gunshot once the cabin caught fire. For a summary of events, see “"'Timeline: The Christopher Dorner manhunt,” Los Angeles Times 8 Feb. 2013, http://timelines.latimes.com/statewide-manhuntex-lapd-officer/.

78 It is worth contrasting the rapid obscurity of the Chris Dorner affair with the national prominence of Trayvon Martin's contemporaneous murder. Despite the entrenched and violent racism that the Dorner case revealed, Dorner's militancy precluded the kind of sympathizing and coalition building that transformed Trayvon Martin into a rallying figure.

79 “We Stand With Christopher Dorner.” Facebook page, 7 Feb. 2013, https://www.facebook.com/WeStandWithChristopherDorner; "We Are All Chris Dorner," Facebook page, 7 Feb. 2013, https://www.facebook.com/WeAreAllChrisDorner/info; "Chris Dorner and the Revolution," Facebook page, accessed 8 Mar. 2013, https://www.facebook.com/ChrisDornerRevolution.

80 See SupremeSpearChuckr, Twitter post, 7 Feb. 2013, 11:45 a.m. https://twitter.com/KingSpearChuckr; Ella Septima-Hamer, Twitter post, 8 Feb. 2013, 10:04 a.m., https://twitter.com/Jbrous14; MadScientistJX, Twitter post, 13 Feb. 2013, 1:09 a.m. https://twitter.com/MadScientistJX (deactivated); and Travis Simpkins, Twitter post, 8 Feb. 2013, 1:34 p.m. https://twitter.com/givegooddick, respectively. See also "Forget Django: Christopher Dorner is now the new Nat Turner," Twitchy.com, 9 Feb. 2013, See "Forget Django: Christoper Dorner is now the new Nat Turner" from conservative pundit Michelle Malkin's Twitter aggregator Twitchy.com for more tweets comparing Dorner with Nat Turner as well as Quentin Tarantino's Django Unchained: http://twitchy.com/2013/02/09/forget-django-christopher-dorner-is-now-the-new-nat-turner/. 
slave, and his retaliation against the LAPD and its loose associates was by no means a slave revolt, just as the militant white supremacy of the LAPD could never constitute actual slavery. Yet as one of the most recent cultural recollections of the rebel slave, the popular discourse surrounding Chris Dorner belongs in the living archive on Nat Turner.

Read alongside Foster's “Knights Templar” and Kyle Baker's Christological iconography, Chris-Dorner-as-Nat-Turner casts into focus anxieties about the blurring of anti-black racism with Islamophobia, this time using Nat Turner as a revolutionary black icon instead of a Christian one in order to distinguish blackness from the image of "the terrorist." While cultural critics like Cornel West ${ }^{81}$ and Janani Balasubramanian ${ }^{82}$ have noted the ways in which antiblackness has informed the state's conduct of its War on Terror as a global form of policing brown people, the Dorner case exemplifies the process reversed: the imperial War on Terror come home as a way to domestically surveil and police blacks within the US.

During the Dorner manhunt, police were alleged to have used unmanned aerial vehicles — the deadly drones that have become the centerpiece of Barack Obama's foreign policy. Reports conflicted as to the veracity of claims that the LAPD deployed the military technology in order to spy out Dorner. Whether drones were deployed or not, the insertion of their sign into the discourse on Chris Dorner, like Obama's rendering as a “terrorist," reveals the slippage between two racial formations in the white imaginary. To be sure, whites have long policed black bodies, from slave patrols to lynch mobs to the parole boards of the New Jim Crow. What has changed since 9/11, though, is the justification for the state's anti-black violence. Once the tools of US white supremacy have been exported abroad for the purpose of "fighting terrorists," the rhetoric of anti-terrorism becomes a new pretense for further escalating and militarizing control of black

81 West, interview.

82 Balasubramanian, "Zimmermans and Drones.” 
and brown people within the US. Conflating domestic and global regimes of racial oppression actually enables, enforces, and reinforces both. As other Nat Turner texts of recent years attempt to do, this popular response to Chris Dorner disaggregates anti-blackness and Islamophobia through an iconographic strategy, using privileged cultural signs to elevate the given subject above criticism. Dorner cannot be our much feared "terrorist" because he is the black freedom fighter Nat Turner, just as Nat Turner cannot be a "terrorist” because he is a Christian crusaderor Christ incarnate.

Ever since news about the 1831 uprising first spread, Nat Turner has meant more than his historical person. As he has done at other critical moments in the past, Nat Turner after 9/11 makes and remakes, defines and elides, race in the US. Recent iterations of the rebel slave's afterlife like Foster's novels, Baker's comic, and Chris Dorner's folk life attempt to redefine blackness and brownness against each other under a white gaze that increasingly regards both as the same and therefore interchangeable—as a priori “criminal," "terroristic," other. Yet in remembering Nat Turner against post-9/11 racial (re)formations, these recent entries in the archive on Nat Turner also reveal the vicissitudes of memory's ongoing political work. To be sure, critics can locate Baker's comic along with Foster's novels and Dorner's folk life within a familiar tradition of liberatory remembrances of slavery. Baker himself avows as much when he describes writing and drawing Nat Turner into dominant history's lacunae. ${ }^{83}$ Nat Turner's afterlife here performs the resistant political-historical project that George Lipsitz has termed “countermemory." ${ }^{84}$

83 Baker, Nat Turner, 6-7.

84 George Lipsitz, Time Passages: Collective Memory and American Popular Culture (Minneapolis: University of Minnesota Press, 1990), 213: "Counter-memory looks to the past for the hidden histories excluded from dominant narratives. But unlike myths that seek to detach events and actions from the fabric of any larger history, counter-memory forces revision of existing histories by supplying new perspectives about the past.” Counter-memory thus also intervenes in the politics of the present. It can serve, as per Paul Gardullo for instance, as “a wellspring of revolutionary action” (275). Writing on the paintings of Aaron Douglas and Jacob 
Yet cultural memories are neither stable nor certain. Slavery's afterlives operate within the complete context of the social present, and they might well make meaning in unexpected ways and with unintended consequences. What radical possibilities have been passed over by Foster's anti-Muslim “Knights Templar,” for example? What other stories about Nat Turner might be told instead of Baker's too familiar Messiah? For all of the liberatory potential of Nat Turner's afterlife, his post-9/11 depictions speak as much to fears of racial conflation as to hopes for cross-racial alliance. In creating counter-representations of culture heroes like Nat Turner in the face of white supremacy, memorializing strategies risk reifying racial meaning at the expense of dynamic, if dangerous, new definitions of race. Critics must attend, then, to the multiple meanings of memory, to the ways in which it stagnates as well as liberates. There is nothing of pessimism here, however, only possibilities - a meditation on racial meaning in its fullest complexity. Indeed, the life and afterlife of Nat Turner point to nothing less than the uncertain, open-ended potential of the past.

Lawrence, Gardullo explains that "they served as examples of a wave of cultural representations that strove to reorient the wider culture's memory of slavery by recovering a sense of slaves' historical agency. They attempted to dismantle the myth of the Old South and mobilize a version of slavery that foregrounded militant resistance, freedom struggles, rebellions and interracial insurgency” (274). See Paul Gardullo, "'Just Keeps Rollin’ Along’: Rebellions, Revolts and Radical Black Memories of Slavery in the 1930s," Patterns of Prejudice 41, No. 3-4 (2007): 271-301, http://www.tandfonline.com/. 